\title{
Pyrogens Enhance $\beta$-Endorphin Release in Hypothalamus and Trigger Fever That Can Be Attenuated by Buprenorphine
}

\author{
Shu-Ming Tsai ${ }^{1}$, Mao-Tsun Lin ${ }^{2} *$, Jhi-Joung Wang ${ }^{2}$, and Wu-Tein Huang ${ }^{3}$ \\ ${ }^{1}$ Institute of Physiology, National Yang-Ming University Medical School, Taipei, Taiwan, 112 \\ ${ }^{2}$ Department of Medical Research, Chi-Mei Medical Center, Tainan, Taiwan, 710 \\ ${ }^{3}$ Department of Health Care Administration, Diwan University, Tainan, Taiwan, 721
}

Received June 10, 2003; Accepted July 18, 2003

\begin{abstract}
At first, we investigated whether both $\beta$-endorphin release level in the hypothalamus and body temperature can be altered after intracerebroventricular (i.c.v.) injection of either lipopolysaccharide (LPS), interleukin-1 $\beta$ (IL-1 $\beta)$, or prostaglandin $\mathrm{E}_{2}\left(\mathrm{PGE}_{2}\right)$ in rats. It was found that in the rat, i.c.v. administration of either LPS $(0.5 \mu \mathrm{g}$ in $10 \mu \mathrm{l}), \mathrm{IL}-1 \beta(10 \mathrm{ng}$ in $10 \mu \mathrm{l})$, or $\mathrm{PGE}_{2}(200 \mathrm{ng}$ in $10 \mu \mathrm{l})$, in addition to producing fever, upregulated the immunoreactivity of $\beta$-endorphin in the preoptic anterior hypothalamus of rat brain. Secondarily, we assessed whether the fever induced by either LPS, IL- $1 \beta$, or $\mathrm{PGE}_{2}$ can be altered by pretreatment with buprenorphine (an opioid receptor antagonist). The results revealed that i.c.v. administration of buprenorphine $(1-10 \mu \mathrm{g}$ in $10 \mu \mathrm{l})$ alone had an insignificant effect on the body temperature. However, the fever induced by i.c.v. injection of either LPS, IL-1 $\beta$, or $\mathrm{PGE}_{2}$ was significantly attenuated by pretreatment with i.c.v. injection of buprenorphine $1 \mathrm{~h}$ before the pyrogen injection in rats. The results suggest that pyrogens enhance $\beta$-endorphin release in the hypothalamus and trigger fever which can be attenuated by buprenorphine, an opioid receptor antagonist.
\end{abstract}

Keywords: buprenorphine, fever, $\beta$-endorphin, pyrogen, preoptic anterior hypothalamus

\section{Introduction}

The systemic response of fever is the result of pathogenic infection. In particular, the release of lipopolysaccharide (LPS) from Gram-negative bacterial cell wall during most infections triggers a febrile response by stimulating monocytes and macrophages to synthesize and release several pyrogenic cytokines such as interleukin-1 (IL-1), tumor necrosis factor (TNF), and interleukin-6 (IL-6) (1). These enter the circulation and reach the endothelial cells of the hypothalamus. From these cells, prostaglandin $\mathrm{E}_{2}\left(\mathrm{PGE}_{2}\right)$ is released into the brain and binds to $\mathrm{EP}_{3}$ receptors on the cells in the hypothalamic thermoregulatory center (2); this is followed by $\mathrm{PGE}_{2}$-induced neuronal mechanisms involving cyclic AMP (3) and neurotransmitters (1) to elevate the temperature set-point, resulting in fever. Among the neurotransmitters involved in the fever induced by cytokines are the endogenous opioid

*Corresponding author. FAX: $+886-6-2517850$

E-mail: mtlin@ym.edu.tw peptide within the preoptic anterior hypothalamus (POAH), a primary central control site for temperature regulation, where opioid receptors are located (4). Because of reports that IL- $\beta$ can induce the secretion of $\beta$-endorphin in the POAH and that $\beta$-endorphin microinjected into the POAH of rat brain can induce hyperthermia $(5,6)$, this raises the possibility that $\beta$-endorphin release level in the POAH can also be altered after intracerebroventricular (i.c.v.) injection of pyrogens.

Buprenorphine is an oripavine-derived narcotic with high affinity for both the $\mu$ and $\kappa$ subtypes of the opiate receptors (7). It possesses an antinociceptive action in both animal pain models (8) and humans with moderateto-severe pain in the clinic (9). In the rat after electrical stimulation of the tail root, buprenorphine displayed a biphasic dose-response curve in the vocalization pain test (8). Acute administration of buprenorphine was also shown to induce typical $\mu$-opioid agonist effects including euphoria, sedation, analgesia, miosis, catalepsy, and decreased gastrointestinal motility $(10-12)$. Buprenorphine can act as an opioid receptor antagonist under 
some conditions. For example, acute administration of buprenorphine can attenuate the behavioral effects of $\mu$ agonists in a rhesus monkey tail-withdrawal test (13). Clinical studies have shown that chronic treatment with buprenorphine can block the effects of morphine, heroin, and hydromorphone $(11,14)$. Thus, it appears that buprenorphine has a desirable therapeutic effect to reduce heroin use in opioid-dependent patients $(14,15)$. Buprenorphine has also been reported to antagonize the diuretic (16) and schedule-controlled effects of $\kappa$ agonists. These findings suggest that buprenorphine is not only a partial $\mu$ agonist and antagonist, but a pure $\kappa$-opioid receptor antagonist as well. Recently, buprenorphine has been shown to be a potent $\mu$-opioid receptor antagonist in brain cells in the $\left.{ }^{35} \mathrm{~S}\right]-\mathrm{GTP}-\gamma$-S functional binding assay (17). Activation of $\mu$-opioid receptor in brain has also been shown to mediate the fever response in rats $(18-21)$. Furthermore, a more recent report showed that the rectal temperature of dogs was decreased to about $36^{\circ} \mathrm{C}$ at 2 to $2.5 \mathrm{~h}$ after sedation with intra-muscular administration of buprenorphine (22). This raises the additional possibility that buprenorphine has an antipyretic action.

Therefore, in order to deal with the question, in the present study, we first investigated whether the $\beta$ endorphin release level in the hypothalamus can be altered following central administration of several pyrogenic substances including LPS, IL- $1 \beta$, and $\mathrm{PGE}_{2}$ in rats. Secondarily, we conducted an experiment to explore whether central administration of buprenorphine has a preventive effect in the development of fever in rats.

\section{Materials and Methods}

\section{Animals}

Male Sprague-Dawley rats, weighing between 250 and $300 \mathrm{~g}$, were used. They had been maintained in a room at $22 \pm 1.0^{\circ} \mathrm{C}$ and were previously accustomed to being restrained in the rat stocks for several hours at a time. Each animal had freedom to move its limbs and neck and was in an alert condition. Between experiments the animals were individually housed in wire-mesh cages with a 12-h light-dark cycle and were fed with dry powder chow, with tap water available ad libitum. All experiments were started between 09.00 and $10.00 \mathrm{~h}$ to minimize the effect of circadian variation in colonic temperature (Tco). All experiments were done in strict compliance with the recommendations for the care and use of laboratory animals and were approved by the Animal Care Committee of Chi-Mei Medical Center (Tainan, Taiwan).

\section{Surgical preparation}

For the administration of drugs into the third cerebral ventricle, stainless-steel cannula, consisting of a guide tube $(0.81 \mathrm{~mm}$ o.d. $)$ with a snug fitting trocar, and a cannula insert, which was introduced into the tube just before injection, were used. The cannula guide tubes with trocars were implanted using the stereotaxic atlas and coordinates of Paxinos and Watson (23): $0.8 \mathrm{~mm}$ posterior to the bregma, $1.4 \mathrm{~mm}$ from the midline, and $3.6 \mathrm{~mm}$ below the dura. The animals were anesthetized with sodium pentobarbitone $\left(6 \mathrm{mg} \cdot 100 \mathrm{~g}^{-1}\right.$, i.p. $)$ and placed in a KOPF stereotaxic apparatus. After appropriately located craniotomy holes had been made, two self, tapping screws were attached to the calvarium of the parietal bones, and then the cannula guide tubes were inserted to the desired depth through the craniotomy holes. They were anchored with fast-drying acrylic dental cement to the cranial surface, which had been scraped clean of periosteum. The cannula insert was connected to a $10 \mu 1$ Hamilton microsyringe by P.E. 10 polyethylene tubing, and the syringe and tubing were filled with silicone fluid to act as a piston. The volume of injection down each cannula was $10 \mu \mathrm{l}$. A period of 1 week was allowed to permit the animals to recover from the operation before experimentation.

\section{Drug solution}

All drug solutions were prepared in pyrogen-free glassware that was heated for $5 \mathrm{~h}$ at $180^{\circ} \mathrm{C}$ before use. All drug solutions were prepared in pyrogen-free sterile $0.9 \%$ saline and passed through $0.22-\mu \mathrm{m}$ Swinnex bacterial filters. A $10-\mu \mathrm{l}$ aliquot containing $0.9 \% \mathrm{NaCl}$, $\mathrm{PGE}_{2}$ (200 ng; Upjohn Laboratories, Kalamazoo, MI, USA), buprenorphine $\mathrm{HCl}(1-10 \mu \mathrm{g}$; Macfarlan Smith, Edinburgh, UK), Escherichia coli lipopolysaccharide (LPS, 0111:B4, $0.5 \mu \mathrm{g}$; Sigma Chemical Co., St. Louis, MO, USA), or IL-1 $\beta$ (10 ng, Sigma) was injected to each animal.

\section{Pyrogen tests}

Each animal was used at an interval of no less than 5 days. Throughout the experiment, Tco was measured every minute with a copper-constantan thermocouple connected to a thermometer (HR1300; Yokogawa, Tokyo). The basal levels of Tco for each animal were allowed to stabilize for at least $90 \mathrm{~min}$ before any injection. Microinjection was made into the third cerebral ventricle through an injecting cannula. The volume of fluid injected over about $10 \mathrm{~s}$ was $10 \mu \mathrm{l}$. The effects of i.c.v. injection of drugs on Tco were assessed in unanesthetized rats at an ambient temperature of $24^{\circ} \mathrm{C}$. 


\section{Immunohistochemistry}

The rats were deeply anesthetized with a overdose of urethane and perfused transcardially with $0.9 \% \mathrm{NaCl}$ followed by $4 \%$ paraformaldehyde. The brains were removed and immersed into $4 \%$ paraformaldehyde for $4 \mathrm{~h}$ and then $20 \%$ sucrose in $0.1 \mathrm{M}$ phosphate buffer for $24 \mathrm{~h}$. For immunocytochemistry, serial cryostat sections (30- $\mu$ m-thick) were cut using a dry ice sliding microtome (type HM 400 R; Leica Microsystems Nussloch $\mathrm{GmbH}$, Nussloch, Germany) and air dried onto poly-Llysine coated slides.

The $\beta$-endorphin antiserum (Peninsula Laboratories, San Carlos, CA, USA) at 1:2,000 dilution was used as primary antibodies for overnight at $4{ }^{\circ} \mathrm{C}$. Sections were then incubated first with biotinylated goat anti-rabbit secondary antibody (diluted 1:500) followed by a streptavidin-conjugated horseradish peroxidase. The presence of antigen/antibody/enzyme complex can be revealed by addition of diaminobenzidine.

\section{Data presentation and statistical analyses}

Area and strength of staining in immunohistochemistry were assessed by two observers independently and blindly at a $400 \times$ magnification and confirmed by a third observer. There was no significant difference among the assessment by the three. The degrees of positivity of immunoreactivity were semiquantitatively graded as 0 for absence of staining, $1+$ for weak, $2+$ for moderate, and $3+$ for strong staining. The fever index (FI), the area under the curve produced in the $1-\mathrm{h}\left(\mathrm{FI}_{1}\right)$ or 4-h $\left(\mathrm{FI}_{4}\right)$ period after the injection of LPS, IL-1 $\beta$, or $\mathrm{PGE}_{2}$, in terms of degrees centigrade per 1 or $4 \mathrm{~h}$ were calculated.

Results are expressed as the mean \pm S.E.M. for $n$ experiments. One way analysis of variance (ANOVA) was used for the factorial experiment, whereas StudentNewman-Keuls' test was used for post hoc multiple comparisons among means. A $P$ value less than 0.05 was considered to indicate a statistically significant difference.

\section{Results}

Figures 1 and 2 show effects of LPS and IL- $1 \beta$ on Tco in saline- and buprenorphine-treated rats. Intracerebroventricular injection of LPS $(0.5 \mu \mathrm{g}$ in $10 \mu \mathrm{l})$ or IL-1 $\beta$ (10 ng in $10 \mu \mathrm{l})$ resulted in a significant increase in Tco that lasted up to $6 \mathrm{~h}$ (end of the observation period). Pretreatment with buprenorphine $(1-10 \mu \mathrm{g}$ in $10 \mu$ l, i.c.v., $1 \mathrm{~h}$ before i.c.v. injection of LPS or IL-1 $\beta$ ) significantly reduced the LPS- or IL- $1 \beta$-induced fever $(P<0.01)$. Control injection of saline $(0.9 \% \mathrm{NaCl}$ solution) or buprenorphine $(1-10 \mu \mathrm{g}$ in $10 \mu \mathrm{l})$ produced no significant change in Tco during the 1-4-h period of observation. The data in terms of fever index are summarized in Table 1.

Figure 3 depicts the time course of the effects of i.c.v. injection of buprenorphine on the fever induced by i.c.v. injection of $\mathrm{PGE}_{2}(200 \mathrm{ng}$ in $10 \mu \mathrm{l})$ in rats. Intracerebroventricular administration of $\mathrm{PGE}_{2}$ produced a significant increase in Tco that lasted up to $60 \mathrm{~min}$. Again, it was found that the $\mathrm{PGE}_{2}$-induced fever was attenuated by pretreatment with buprenorphine (as shown in both Fig. 3 and Table 1).

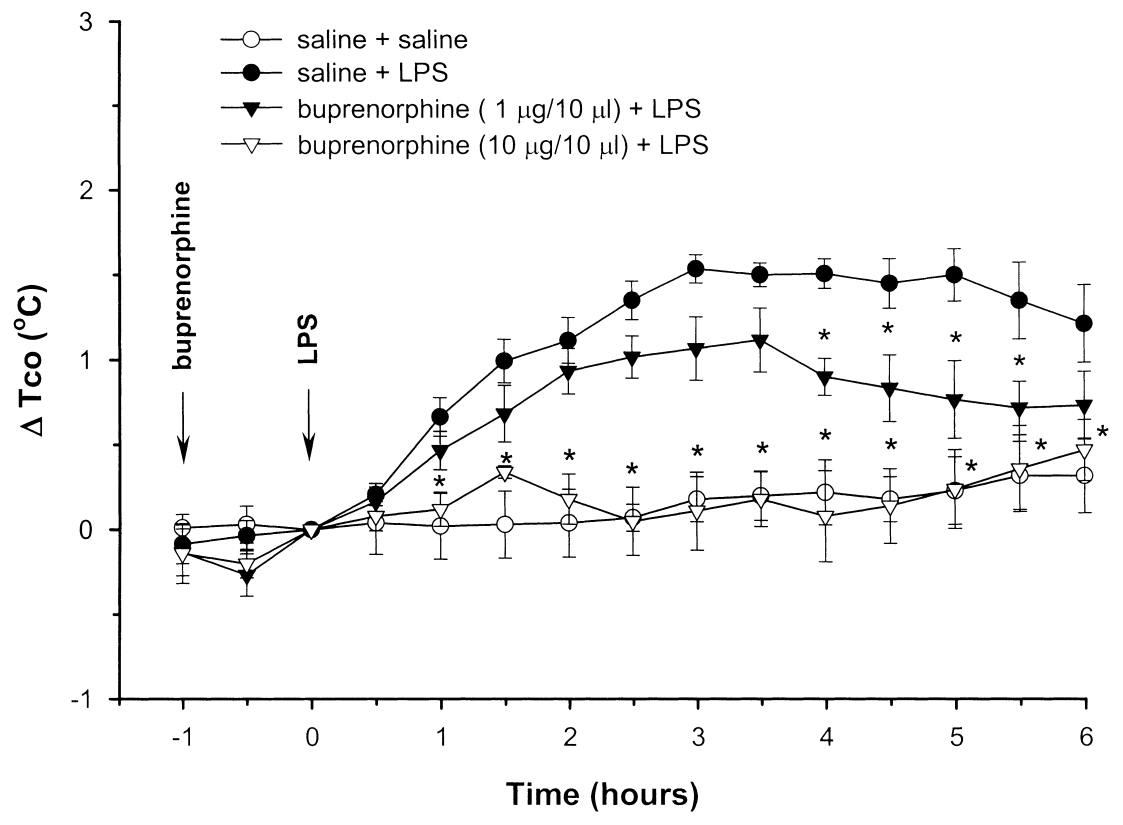

Fig. 1. Time course of the effects of buprenorphine in pyrogenic fever induced by intracerebroventricular administration of LPS. Buprenorphine $(1$ and $10 \mu \mathrm{g} / 10 \mu \mathrm{l})$ was injected intracerebroventricularly $1 \mathrm{~h}$ before LPS $(0.5 \mu \mathrm{g} / 10 \mu \mathrm{l})$ injected at time $0 \mathrm{~h}$. The values are the mean \pm S.E.M. of 8 rats per group. ${ }^{*} P<0.05$, significantly different from the corresponding control values (saline + LPS group) (ANOVA followed by Student-Newman-Keuls' test). 


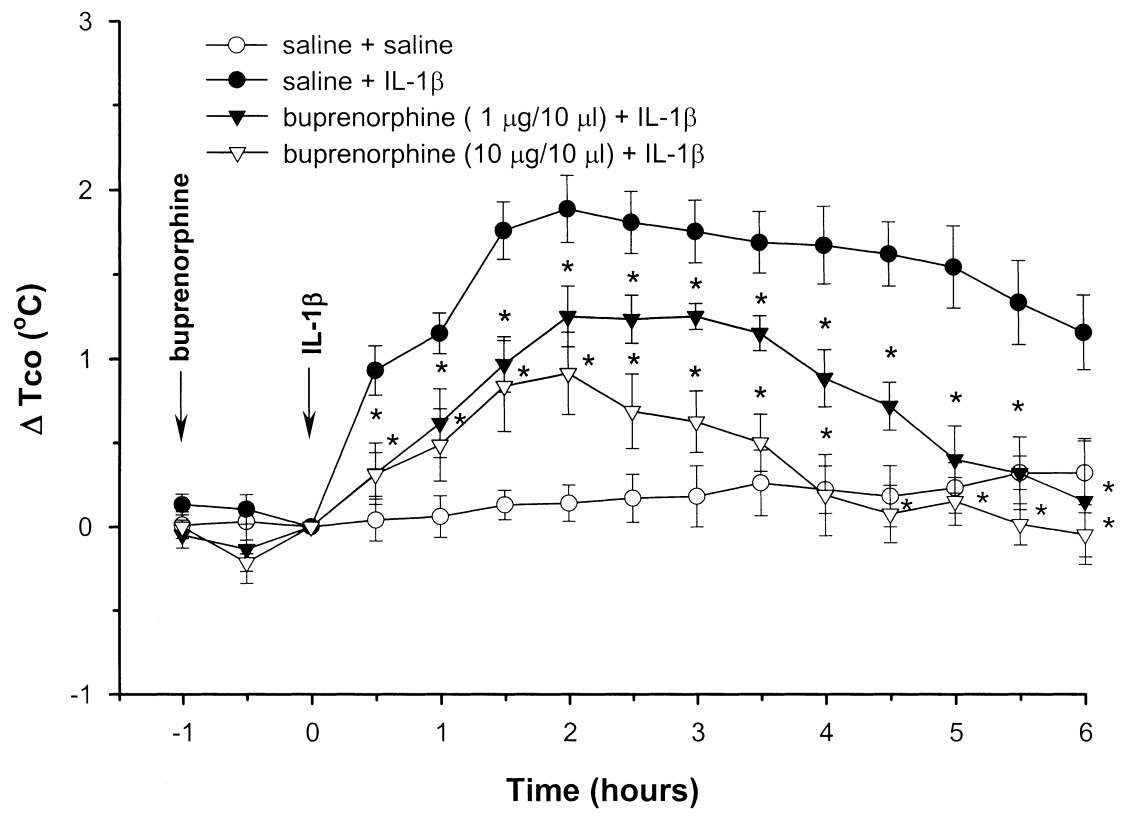

Fig. 2. Time course of the effects of buprenorphine in pyrogenic fever induced by intracerebroventricular administration of IL-1 $\beta$. Buprenorphine $(1$ and $10 \mu \mathrm{g} / 10 \mu \mathrm{l})$ was injected intracerebroventricularly $1 \mathrm{~h}$ before IL$1 \beta(10 \mathrm{ng} / 10 \mu \mathrm{l})$ injected at time $0 \mathrm{~h}$. The values are the mean \pm S.E.M. of 8 rats per group. $* P<0.05$, significantly different from the corresponding control values (saline + IL$1 \beta$ group) (ANOVA followed by StudentNewman-Keuls' test).

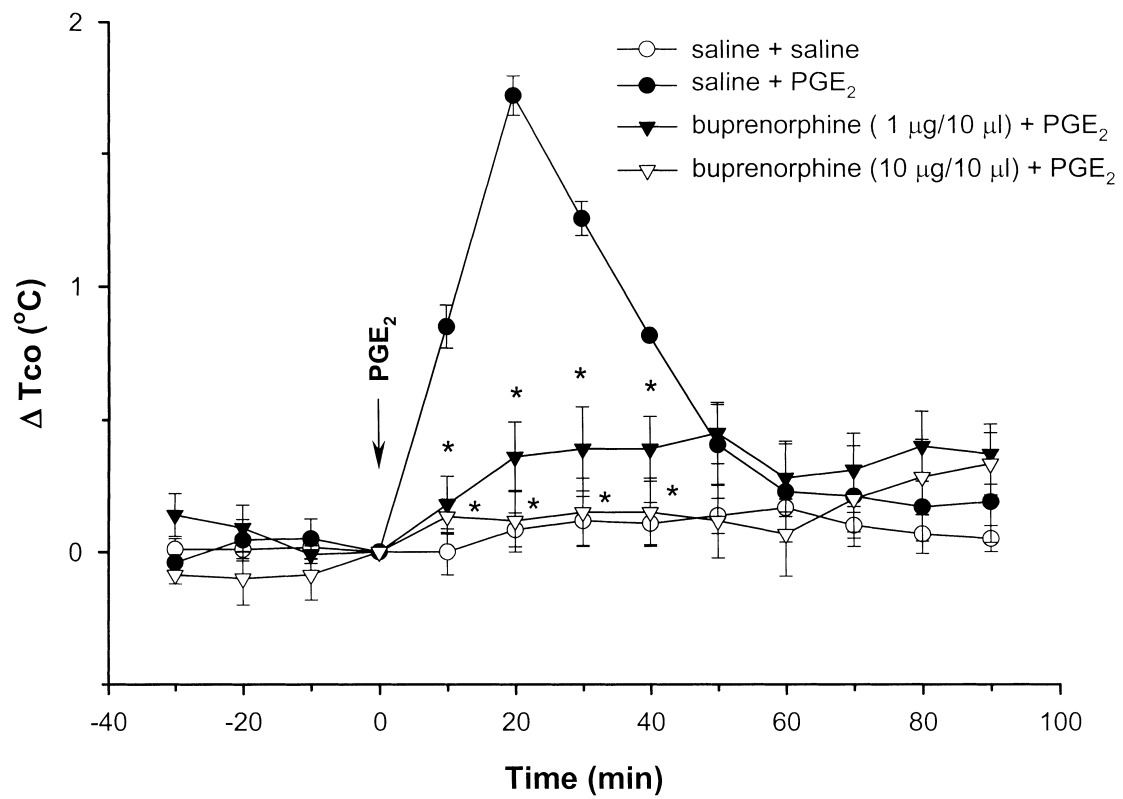

Fig. 3. Time course of the effects of buprenorphine in pyrogenic fever induced by intracerebroventricular administration of $\mathrm{PGE}_{2}$. Buprenorphine (1 and $10 \mu \mathrm{g} / 10 \mu \mathrm{l})$ was injected intracerebroventricularly $60 \mathrm{~min}$ before $\mathrm{PGE}_{2}(200 \mathrm{ng} / 10 \mu \mathrm{l})$ injected at time $0 \mathrm{~min}$. The values are the mean \pm S.E.M. of 8 rats per group. ${ }^{*} P<0.05$, significantly different from the corresponding control values (saline + $\mathrm{PGE}_{2}$ group) (ANOVA followed by StudentNewman-Keuls' test).
Brain sections from normothermic rats pretreated with i.c.v. injection of $0.9 \% \mathrm{NaCl}$ solution expressed no or weak positive activity of immunoreactive $\beta$-endorphin in the POAH of the hypothalamus (Fig. 4A). The hypothalamic regions in hyperthermic rats treated with an i.c.v. injection of either LPS $(0.5 \mu \mathrm{g}), \mathrm{PGE}_{2}(200 \mathrm{ng})$, or IL-1 $\beta$ (10 ng) alone showed stronger immunoreactivity for $\beta$-endorphin than those in control sections (Fig. 4: $\mathrm{B}-\mathrm{D})$. The immunoreactive data are summarized in Table 2.

\section{Discussion}

Our present results demonstrate that $\beta$-endorphin release or synthesis in the POAH of rat brain (as demonstrated by immunochemical staining technique) is increased after i.c.v. administration of LPS. The results are in part consistent with the findings of Carr et al. (24). They reported that increases in plasma, cerebrospinal fluid and hypothalamic levels of $\beta$-endorphin (which acts on $\mu$-opioid receptors) was observed during systemic administration of LPS. $\beta$-Endorphin micro- 
Table 1. Effects of intracerebroventricular administration of buprenorphine $1 \mathrm{~h}$ before the pyrogen injection on the febrile response to intracerebroventricular injection of LPS, IL- $1 \beta$, or $\mathrm{PGE}_{2}$ in rats

\begin{tabular}{|c|c|c|}
\hline Treatments & Fever index $\left(\mathrm{FI},{ }^{\circ} \mathrm{C} \cdot \mathrm{h}\right)$ & F values \\
\hline Saline $(10 \mu \mathrm{l})+$ Saline $(10 \mu \mathrm{l})$ & $\mathrm{FI}_{4}=0.35 \pm 0.13$ & 60.361 \\
\hline Buprenorphine $(10 \mu \mathrm{g} / 10 \mu \mathrm{l})+$ Saline & $\mathrm{FI}_{4}=0.45 \pm 0.18$ & \\
\hline Saline + LPS $(0.5 \mu \mathrm{g} / 10 \mu \mathrm{l})$ & $\mathrm{FI}_{4}=4.06 \pm 0.26^{*}$ & \\
\hline Buprenorphine $(1 \mu \mathrm{g} / 10 \mu \mathrm{l})+\mathrm{LPS}(0.5 \mu \mathrm{g} / 10 \mu \mathrm{l})$ & $\mathrm{FI}_{4}=2.95 \pm 0.21^{\dagger}$ & \\
\hline Buprenorphine $(10 \mu \mathrm{g} / 10 \mu \mathrm{l})+\mathrm{LPS}(0.5 \mu \mathrm{g} / 10 \mu \mathrm{l})$ & $\mathrm{FI}_{4}=0.55 \pm 0.29^{\dagger}$ & \\
\hline Saline $(10 \mu \mathrm{l})+$ Saline $(10 \mu \mathrm{l})$ & $\mathrm{FI}_{4}=0.55 \pm 0.15$ & 37.154 \\
\hline Buprenorphine $(10 \mu \mathrm{g} / 10 \mu \mathrm{l})+$ Saline & $\mathrm{FI}_{4}=0.65 \pm 0.22$ & \\
\hline Saline $+\mathrm{IL}-1 \beta(10 \mathrm{ng} / 10 \mu \mathrm{l})$ & $\mathrm{FI}_{4}=5.90 \pm 0.32 *$ & \\
\hline Buprenorphine $(1 \mu \mathrm{g} / 10 \mu \mathrm{l})+\mathrm{IL}-1 \beta(10 \mathrm{ng} / 10 \mu \mathrm{l})$ & $\mathrm{FI}_{4}=3.61 \pm 0.42^{\dagger}$ & \\
\hline Buprenorphine $(10 \mu \mathrm{g} / 10 \mu \mathrm{l})+\mathrm{IL}-1 \beta(10 \mathrm{ng} / 10 \mu \mathrm{l})$ & $\mathrm{FI}_{4}=2.23 \pm 0.57^{\dagger}$ & \\
\hline Saline $(10 \mu \mathrm{l})+$ Saline $(10 \mu \mathrm{l})$ & $\mathrm{FI}_{1}=0.09 \pm 0.04$ & 33.816 \\
\hline Buprenorphine $(10 \mu \mathrm{g} / 10 \mu \mathrm{l})+$ Saline & $\mathrm{FI}_{1}=0.10 \pm 0.05$ & \\
\hline Saline $+\mathrm{PGE}_{2}(200 \mathrm{ng} / 10 \mu \mathrm{l})$ & $\mathrm{FI}_{1}=0.85 \pm 0.07 *$ & \\
\hline Buprenorphine $(1 \mu \mathrm{g} / 10 \mu \mathrm{l})+\mathrm{PGE}_{2}(200 \mathrm{ng} / 10 \mu \mathrm{l})$ & $\mathrm{FI}_{1}=0.32 \pm 0.07^{\dagger}$ & \\
\hline Buprenorphine $(10 \mu \mathrm{g} / 10 \mu \mathrm{l})+\mathrm{PGE}_{2}(200 \mathrm{ng} / 10 \mu \mathrm{l})$ & $\mathrm{FI}_{1}=0.12 \pm 0.04^{\dagger}$ & \\
\hline
\end{tabular}

The values are means \pm S.E.M. of 8 rats per group. $\mathrm{FI}_{4}$ and $\mathrm{FI}_{1}$ represent fever index for 4 and $1 \mathrm{~h}$, respectively. *Significantly different from the corresponding control value (saline plus saline group) $(P<0.01$, one way analysis of variance of variance followed by Student-Newman-Keuls' test); 'Significantly different from the corresponding control value (saline plus LPS, saline plus IL-1 $\beta$, or saline plus $\mathrm{PGE}_{2}$ group) $(P<0.01$, one way analysis of variance of variance followed by Student-Newman-Keuls' test).
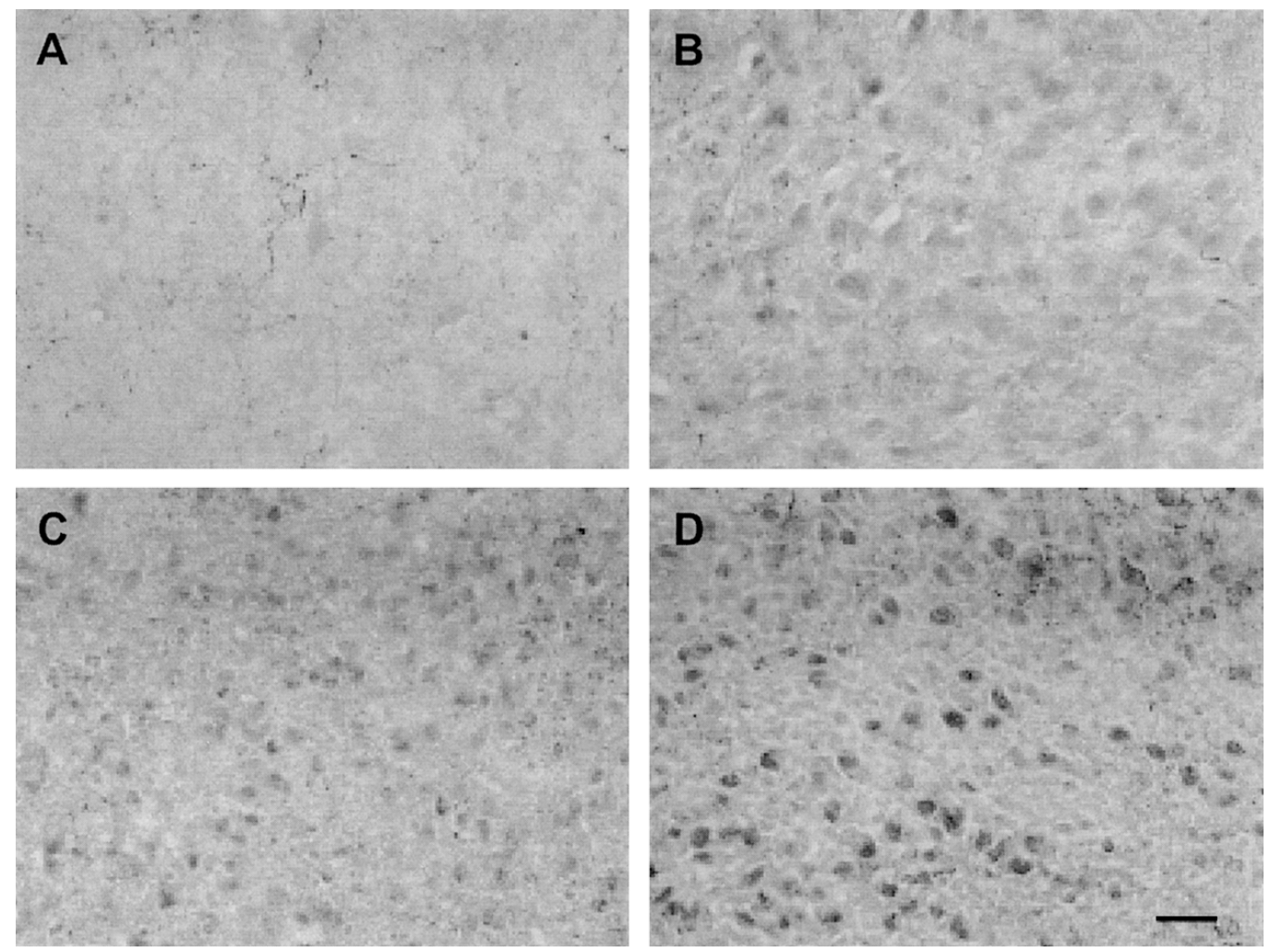

Fig. 4. $\beta$-Endorphin expression in the preoptic anterior hypothalamus induced by intracerebroventricular injection of saline (A), $\mathrm{PGE}_{2}$ (B), IL-1 $\beta$ (C), and LPS (D). Animals were killed $20 \mathrm{~min}, 2 \mathrm{~h}$, and $4 \mathrm{~h}$ after PGE $\mathrm{I}_{2}$, IL-1 $\beta$, and LPS injection for immunohistochemistry experiment, respectively. Scale bar, $30 \mu \mathrm{m}$. 
Table 2. Expression of $\beta$-endorphin in the hypothalamus as well as colonic temperatures from saline-, $\mathrm{PGE}_{2-}$, IL- $1 \beta$-, and LPS-treated rats by $20 \mathrm{~min}, 2 \mathrm{~h}$, and $4 \mathrm{~h}$ after $\mathrm{PGE}_{2}$, IL- $1 \beta$, and LPS injection for immunohistochemical studies, respectively

\begin{tabular}{|c|c|c|c|}
\hline Number & Rat & Immunohistochemistry $^{\mathrm{a}}$ & $\operatorname{Tco}\left({ }^{\circ} \mathrm{C}\right)$ \\
\hline 1 & Saline-treated & $1+$ & 36.8 \\
\hline 2 & Saline-treated & $1+$ & 36.7 \\
\hline 3 & Saline-treated & 0 & 37.0 \\
\hline 4 & Saline-treated & 0 & 37.1 \\
\hline 5 & Saline-treated & $1+$ & 36.5 \\
\hline 6 & $\mathrm{PEG}_{2}$-treated & $3+$ & 38.8 \\
\hline 7 & $\mathrm{PEG}_{2}$-treated & $3+$ & 39.2 \\
\hline 8 & $\mathrm{PEG}_{2}$-treated & $3+$ & 38.9 \\
\hline 9 & $\mathrm{PEG}_{2}$-treated & $3+$ & 39.4 \\
\hline 10 & $\mathrm{PEG}_{2}$-treated & $3+$ & 39.3 \\
\hline 11 & IL- $1 \beta$-treated & $2+$ & 39.5 \\
\hline 12 & IL- $1 \beta$-treated & $1+$ & 39.3 \\
\hline 13 & IL- $1 \beta$-treated & $1+$ & 39.4 \\
\hline 14 & IL- $1 \beta$-treated & $2+$ & 39.5 \\
\hline 15 & IL- $1 \beta$-treated & $2+$ & 39.6 \\
\hline 16 & LPS-treated & $3+$ & 38.4 \\
\hline 17 & LPS-treated & $3+$ & 39.0 \\
\hline 18 & LPS-treated & $3+$ & 38.9 \\
\hline 19 & LPS-treated & $3+$ & 39.0 \\
\hline 20 & LPS-treated & $3+$ & 39.2 \\
\hline
\end{tabular}

a Staining was scored as follows: 0, no staining; 1+, weak staining; $2+$, moderate staining; $3+$, strong staining.

injected locally into the POAH also produced fever that was blocked by pretreatment with CTAP (the $\mu$ opioid receptor-selective antagonist) $(6,25)$. These findings are compatible with the contention that the $\beta$ endorphin system in the brain is involved in the mediation of febrile response to LPS.

Evidence has accumulated to suggest that increase in several pyrogenic substances including IL- $1 \beta$, TNF- $\alpha$, and macrophage inflammatory protein-1 (MIP-1) accompanied by fever can be induced by LPS (26-28). The fever induced by systemic administration of LPS or central administration of IL- $1 \beta$, TNF- $\alpha$, or MIP- 1 can be prevented by pretreatment with intra-POAH injection of CTAP $(20,21,25,29)$. Both the present and previous $(5,25)$ results further demonstrated that the level of $\beta$ endorphin release in the POAH was increased after i.c.v. or intracerebral administration of either IL- $1 \beta, \mathrm{PGE}_{2}$, or TNF- $\alpha$. These observations prompted us to think that the antagonism of LPS-induced fever by CATP may result from the prevention of binding of $\beta$-endorphin, produced by these pyrogenic cytokines or $\mathrm{PGE}_{2}$, to the $\mu$-opioid receptors in the POAH of rat brain.

The aforementioned statement is supported by several previous findings. For example, intracerebral administration of $\mu$-opioid receptor selective agonist produced hyperthermia which can be blocked by pretreatment with the $\mu$-opioid receptor antagonist $(18,30)$. On the other hand, central injection of the $\kappa$-opioid receptor agonist induces hypothermia that can be blocked by $\kappa$ selective opioid receptor antagonist in rats (30). The $\delta$ opioid receptors do not appear to be involved in body temperature regulation (30).

As mentioned before in the introduction section, buprenorphine is not only a partial $\mu$-opioid receptor agonist and antagonist, but a pure $\kappa$-opioid receptor antagonist as well. A more recent report has also demonstrated that buprenorphine is a potent and selective $\mu / \kappa$ opioid receptor antagonist in the $\left[{ }^{35} \mathrm{~S}\right]-\mathrm{GTP}-\gamma-\mathrm{S}$ functional binding assay in guinea pig caudate membranes (17). In the present results, the fever induced by i.c.v. administration of LPS, IL- $1 \beta$, or $\mathrm{PGE}_{2}$ was attenuated by pretreatment with i.c.v. injection of buprenorphine in rats. Thus, it appears that the antagonism of pyrogenic fever by buprenorphine may result from the antagonism of the $\mu$-opioid receptors in the POAH of rat brain. This hypothesis is in part supported by the previous results $(13,18,30)$. For example, buprenorphine was able to antagonize the antinociceptive effects of several selective $\mu$-opioid receptor agonists in a rhesus monkey tailwithdrawal test (13). In addition, activation of central $\mu$-opioid receptors induced fever reactions $(18,30)$. However, as shown in Table 2, the release of $\beta$-endorphin in rat POAH is less involved in the hyperthermia induced by IL- $1 \beta$ than those by LPS and $\mathrm{PGE}_{2}$. This contention is supported by the data presented in Fig. 2 that unlike the fever induced by LPS and $\mathrm{PGE}_{2}$, the fever induced by IL- $1 \beta$ was not completely attenuated by buprenorphine. In fact, the $\kappa$-selective antagonist nor-BNI failed to block an MIP- $1 \beta$-induced fever-like hyperthermia. However, pretreatment with either $\mu$ selective antagonists, $\beta$-FNA or CTAP, blocked MIP$1 \beta$-induced fever while having no effect on IL- $1 \beta$ induced fever (21). These suggest that in homeotherms, there are multiple pathways for the induction of fever.

Other lines of evidence has accumulated to indicate that the $5 \mathrm{HT}_{2 \mathrm{~A}}$ and $5-\mathrm{HT}_{1 \mathrm{~A}}$ receptors activation in the hypothalamus mediate the hyperthermic and hypothermic action, respectively, in rats (31). It was also shown that 5-HT, either endogenous or exogenously delivered, facilitate the release of $\beta$-endorphin in the arcuate nucleus and nucleus accumbens (32). According to the findings of Gemma et al. (33), activation of the hypothalamic serotonergic system was produced by central injection of IL-1 $\beta$. Systemic administration of $5-\mathrm{HT}_{2 \mathrm{~A}}$-receptor agonists such as DOI, MK212, or quipazine caused fever in rats (34). The induced fever 
was antagonized by pretreatment with $5-\mathrm{HT}_{2 \mathrm{~A}}$-receptor antagonists (35). Direct injection of DOI into the rat's hypothalamus also caused fever (36). Our unpublished data further showed that the fever induced by LPS, IL- $1 \beta$, or $\mathrm{PGE}_{2}$ in rats could be attenuated by pretreatment with $5-\mathrm{HT}_{2 \mathrm{~A}}$-receptor antagonists cyproheptadine, ketanserin, or mianserin. The fever induced by central injection of the 5- $\mathrm{HT}_{2 \mathrm{~A}}$-receptor agonist DOI was also reduced by pretreatment with central injection of either $5-\mathrm{HT}_{2 \mathrm{~A}}$-receptor antagonists or the opioid receptor antagonist buprenorphine. These results suggest that 5$\mathrm{HT}_{2 \mathrm{~A}}-\mu$-opioid receptor mechanisms in the hypothalamus mediate pyrogen fever in rats. In the present results, pyrogenic agents such as LPS, IL- $1 \beta$, and $\mathrm{PGE}_{2}$ may have stimulated $5-\mathrm{HT}_{2 \mathrm{~A}}$ receptors in the POAH and resulted in $\beta$-endorphin release in the POAH; excessive accumulation of $\beta$-endorphin in situ may have activated the $\mu$-opioid receptors in the POAH and resulted in fever.

In summary, the present results showed that central injection of pyrogenic cytokines or $\mathrm{PGE}_{2}$ stimulated the synthesis or release of $\beta$-endorphin in the hypothalamus and induced fever in rats. The fever induced by central injection of either LPS, IL-1 $\beta$, or $\mathrm{PGE}_{2}$ could be attenuated by pretreatment with buprenorphine, probably via the antagonism of $\mu$-opioid receptors in the brain.

\section{Acknowledgments}

This work was supported by grants from the National Science Council (NSC 90-2316-B-010-009) and the Ministry of Education (89-B-FA22-1-4-02) of Taiwan. Dr. Mao-Tsun Lin was given an award by the Medical Research and Advancement Foundation in Memory of Dr. Chi-Shuen Tsou.

\section{References}

1 Dinarello CA, Gatti S, Bartfai T. Fever: links with an ancient receptor. Curr Biol. 1999;9:R147-R150.

2 Ushikubi F, Sugimoto Y, Ichikawa A, Narumiya S. Roles of prostanoids revealed from studies using mice lacking specific prostanoid receptors. Jpn J Pharmacol. 2000;83:279-285.

3 Lin MT, Wu JJ, Chandra A, Tsay BL. A norepinephrine-cyclic AMP link in the hypothalamic pathways which mediate fever induced by endotoxin and prostaglandin $\mathrm{E}_{2}$ in the rat. J Pharmacol Exp Ther. 1982;222:251-257.

4 Mansour A, Khachaturian H, Lewis ME, Akil H, Watson SJ. Autoradiographic differentiation of $\mu, \kappa$, and $\delta$ opioid receptors in the rat forebrain and midbrain. J Neurosci. 1987;7:2445-2464.

5 Zhao SF, Xin L, Geller EB, Adler MW. Blockade by $\mu$ - and $\delta$ opioid receptor antagonists of hyperthermia induced by tumor necrosis factor- $\alpha$ and $\beta$-endorphin. Analgesia. 1995;1:878-881.

6 Lin MT, Chern YF, Chen SY. Depletion of noradrenaline in the hypothalamus reduces the febrile responses induced by prostaglandin $\mathrm{E}_{2}$, thyrotropin-releasing hormone and $\beta$-endorphin in rats. Neuropharmacology. 1985;24:1039-1042.

7 Sadee W, Richards ML, Grevel J, Rosenbaum JS. In vivo characterization of four types of opioid binding sites in rat brain. Life Sci. 1983;33 Suppl 1:187-189.

8 Dum JE, Herz A. In vivo receptor binding of the opiate partial agonist, buprenorphine, correlated with its agonistic and antagonistic actions. Br J Pharmacol. 1981;74:627-633.

9 Wnendt S, Kruger T, Janocha E, Hildebrandt D, Englberger W. Agonistic effect of buprenorphine in a nociceptin/OFQ receptortriggered reporter gene assay. Mol Pharmacol. 1999;56:334338.

10 Cowan A, Lewis JW, Macfarlane IR. Agonist and antagonist properties of buprenorphine, a new antinociceptive agent. Br J Pharmacol. 1977;60:537-545.

11 Jasinski DR, Pevnick JS, Griffith JD. Human pharmacology and abuse potential of the analgesic buprenorphine: a potential agent for treating narcotic addiction. Arch Gen Psychiatry. 1978; 35:501-516.

12 Heel RC, Brogden RN, Speight TM, Avery GS. Buprenorphine: a review of its pharmacological properties and therapeutic efficacy. Drugs. 1979;17:81-110.

13 Walker EA, Zernig G, Woods JH. Buprenorphine antagonism of $\mu$ opioids in the rhesus monkey tail-withdrawal procedure. $\mathrm{J}$ Pharmacol Exp Ther. 1995;273:1345-1352.

14 Mello NK, Mendelson JH. Buprenorphine suppresses heroin use by heroin addicts. Science. 1980;207:657-659.

15 Johnson RE, Jaffe JH, Fudala PJ. A controlled trial of buprenorphine treatment for opioid dependence. JAMA. 1992;267:27502755.

16 Leander JD. Opioid agonist and antagonist behavioural effects of buprenorphine. Br J Pharmacol. 1983;78:607-615.

17 Romero DV, Partilla JS, Zheng QX, et al. Opioid peptide receptor studies. 12. Buprenorphine is a potent and selective $\mu / \kappa$ antagonist in the $\left[{ }^{35} \mathrm{~S}\right]-\mathrm{GTP}-\gamma-\mathrm{S}$ functional binding assay. Synapse. 1999;34:83-94.

18 Benamar K, Geller EB, Adler MW. Effect of a $\mu$-opioid receptor-selective antagonist on interleukin-6 fever. Life Sci. 2002;70:2139-2145.

19 Mayfield KP, Kozak A, Rudolph K, Kluger MJ. Morphine suppresses development of fever to lipopolysaccharide in rats. Ann NY Acad Sci. 1998;856:281-285.

20 Benamar K, Xin L, Geller EB, Adler MW. Blockade of lipopolysaccharide-induced fever by a $\mu$-opioid receptorselective antagonist in rats. Eur J Pharmacol. 2000;401:161-165.

21 Handler CM, Price RW, Geller EB, Adler MW. Effect of $\mu$ selective opioid antagonists on MIP- $1 \beta$ and IL- $\beta$-induced fever. Ann NY Acad Sci. 1998;856:270-273.

22 Orito K, Imaizumi T, Yoshida K, Kishi M, Fujiki H, Mori T. Effect of oral OPC-28326, a selective femoral arterial vasodilator, on hindlimb subcutaneous tissue temperature in onscious dogs under buprenorphine sedation. Jpn J Pharmacol. 2002; 88:119-122.

23 Paxinos G, Watson C. The rat brain in stereotaxic coordinates. New York: Academic Press, 1982.

24 Carr DB, Bergland R, Hamilton A, et al. Endotoxin-stimulated opioid secretion: two secretory pools and feedback control in vivo. Science. 1982;217:845-848.

25 Xin L, Zhao SF, Geller EB, McCafferty MR, Sterling GH, 
Adler MW. Involvement of $\beta$-endorphin in the preoptic anterior hypothalamus during interleukin- $\beta$-induced fever in rats. Ann NY Acad Sci. 1997;813:324-326.

26 Long NC, Otterness I, Kunkel SL, Vander AJ, Kluger MJ. Roles of interleukin- $\beta$ and tumor necrosis factor in lipopolysaccharide fever in rats. Am J Physiol. 1990;259:R724-R728.

27 Nakamori T, Morimoto A, Yamaguchi K, Watanabe T, Murakami N. Interleukin- $\beta$ production in the rabbit brain during endotoxin-induced fever. J Physiol (Lond). 1994;476: 177-186.

28 Miñano FJ, Fernández-Alonso A, Benamar K, et al. Macrophage inflammatory protein- $\beta$ (MIP-1 $\beta$ ) produced endogenously in brain during E. coli fever in rats. Eur J Neurosci. 1996;8:424428.

29 Blatteis CM, Xin L, Quan N. Neuromodulation of fever: apparent involvement of opioids. Brain Res Bull. 1991;26:219-223.

30 Adler MW, Geller EB. Physiological functions of opioids: Temperature regulation. In: Herz A, Akil H, Simon EJ, editors. Handbook of experimental pharmacology. Beilin: SpringerVerlag; 1992. p. 205-238.

31 Lin MT, Chuang JI. Melatonin potentiates $5-\mathrm{HT}_{1 \mathrm{~A}}$ receptor activation in rat hypothalamus and results in hypothermia. $\mathrm{J}$ Pineal Res. 2002;33:14-19.

32 Zangen A, Nakash R, Yadid G. Serotonin-mediated increases in the extracellular levels of $\beta$-endorphin in the arcuate nucleus and nucleus accumbens: a microdialysis study. J Neurochem. 1999; 73:2569-2574

33 Gemma C, Ghezzi P, De Simoni MG. Activation of the hypothalamic serotoninergic system by central interleukin-1. Eur J Pharmacol. 1991;209:139-140.

34 Hutson PH, Donohoe TP, Curzon G. Hypothermia induced by the putative $5-\mathrm{HT}_{1 \mathrm{~A}}$ agonists LY165163 and 8-OH-DPAT is not prevented by 5-HT depletion. Eur J Pharmacol. 1987;143:221228.

35 Mazzola-Pomietto P, Aulakh CS, Wozniak KM, Hill JL, Murphy DL. Evidence that 1-(2,5-dimethoxy-4-iodophenyl)-2aminopropane (DOI)-induced hyperthermia in rats is mediated by stimulation of $5-\mathrm{HT}_{2 \mathrm{~A}}$ receptors. Psychopharmacology (Berl). 1995;117:193-199.

36 Lin MT, Tsay HJ, Su WH, Chueh FY. Changes in extracellular serotonin in rat hypothalamus affect thermoregulatory function. Am J Physiol. 1998;274:R1260-R1267. 